\title{
Detection of survivin expression in bladder cancer and renal cell carcinoma using specific monoclonal antibodies
}

\author{
DONGMEI CHEN, JIANJUN XU and QINGYUN ZHANG
}

\begin{abstract}
Key Laboratory of Carcinogenesis and Translational Research (Ministry of Education), Department of Clinical Laboratory, Peking University School of Oncology, Peking University Cancer Hospital and Institute, Beijing 100142, P.R. China
\end{abstract}

Received April 18, 2016; Accepted March 30, 2018

DOI: $10.3892 /$ or.2018.6359

\begin{abstract}
Survivin, which is highly expressed in the majority of tumors, but not in most normal adult tissues, has been identified to have significant clinical applications. In the present study, using survivin-specific monoclonal antibodies (mAbs), we aimed to establish methods for detecting the expression of survivin in cancer cell lines, serum samples, urine samples and cancer tissues from patients with bladder cancer $(\mathrm{BCa})$ and renal cell carcinoma (RCC), and to evaluate the efficacy of survivin as a tumor marker in the surveillance of $\mathrm{BCa}$ and RCC. First, mAbs were labeled with horseradish peroxidase (HRP), and a sandwich enzyme-linked immunosorbent assay (ELISA) with mAbs and HRP-conjugated mAbs was developed to detect survivin expression in serum and urine samples from BCa and RCC patients, with samples from healthy controls (HCs) used for comparison. The HRP-conjugated mAbs were also used to detect survivin expression in cancer cell lines by western blotting. Survivin expression in cancer tissues from BCa patients was also evaluated by immunohistochemistry. The results showed that the sandwich ELISA was successfully established, and significantly higher expression of survivin was subsequently detected in $\mathrm{BCa}$ and RCC patients as compared with $\mathrm{HCs}$ in both urinary and serum samples $(\mathrm{P}<0.05)$, and was more pronounced in urine. The HRP-mAbs could recognize survivin in cancer cell lines. Western blotting and immunohistochemistry results confirmed survivin expression in the $5637 \mathrm{BCa}$ cell line, as well as BCa tissues. In addition, the expressions of survivin in $\mathrm{BCa}$ tissues, urine and serum were consistent in our study. In conclusion, the sandwich ELISA successfully established in the present study was of high sensitivity and specificity in the detection of survivin
\end{abstract}

Correspondence to: Dr Qingyun Zhang, Key Laboratory of Carcinogenesis and Translational Research (Ministry of Education), Department of Clinical Laboratory, Peking University School of Oncology, Peking University Cancer Hospital and Institute, 52 Fucheng Road, Haidian, Beijing 100142, P.R. China

E-mail: zhqy_208@163.com

Key words: survivin, monoclonal antibody, bladder cancer, renal cell carcinoma, enzyme-linked immunosorbent assay, tumor marker expression. The results also indicated that survivin is a potential tumor marker for the surveillance of $\mathrm{BCa}$ and $\mathrm{RCC}$.

\section{Introduction}

Survivin, also known as baculovirus IAP repeat-containing protein 5 (BIRC5) and apoptosis inhibitor 4 (API4), is a member of the inhibitor of apoptosis protein (IAP) family (1), which all contain at least one copy of a baculovirus IAP repeat (BIR) domain, and suppress apoptosis when overexpressed in cells $(2,3)$. Previous studies have shown that survivin participates in the suppression of apoptosis, as well as the regulation of cell division (4-6).

Survivin is a homodimer of a $16.5-\mathrm{kDa}$ protein (7). Located at the tip of chromosome 17 in humans (17q25), the survivin gene has four dominant (1,2,3, and 4) and two hidden (2B and $3 \mathrm{~B}$ ) exons. Alternative splicing of its pre-mRNA produces splice variants, five of which are known as survivin wild-type (wt), survivin-2B, survivin-DEx3 (8), survivin-3B (9) and survivin $2 \alpha(10)$.

It has been demonstrated that the vast majority of tumors express Survivin mRNA and protein at high levels, whereas most normal adult tissues do not, suggesting that survivin expression is commonly associated with cancer (1,11-13). Survivin may be localized inside or outside the cell (14); inside the cell, survivin has been observed in the cytoplasm, the nucleus and the mitochondria (15-17), but it may also be released into the extracellular space through vesicles (14-18).

In previous studies, it was demonstrated that active caspase-3 and -7 co-immunoprecipitated with survivin, whereas their inactive pro-forms did not $(19,20)$. This interaction disrupts the caspase cascade and cleavage mediated by caspases, thereby resulting in decreased apoptosis (21). In a similar manner, survivin inhibits cytochrome $c$ - and caspase-8-induced DEVD (Asp-Glu-Val-Asp)-cleavage activity (21). Previous studies also revealed that survivin antisense oligonucleotides target and downregulate survivin mRNA and induce apoptosis $(22,23)$. Survivin contains a $\mathrm{CDE} / \mathrm{CHR}$ element, which is involved in cell cycle-specific regulation, implying that survivin may be involved in the cell cycle process (24). During mitosis, survivin can interact with CDK1 (24). Survivin can also interact with the cell cycle regulator $\mathrm{CDK} 4$, leading to $\mathrm{CDK} 2$ /cyclin $\mathrm{E}$ activation and $\mathrm{Rb}$ phosphorylation. In a previous study, forced overexpression of 
survivin resulted in an accelerated $\mathrm{S}$ phase and resistance to $\mathrm{G} 1$ arrest (25). Survivin, Borealin, INCENP and Aurora B kinase are components of the chromosomal passenger complex (CPC), which is a key regulator of chromosome segregation and cytokinesis during cell division (26,27). Knockdown of survivin expression was found to inhibit cell proliferation, arrest the cell cycle at the G2/M checkpoint and induce cellular apoptosis (28). Previous studies also showed that survivin participates in cell autophagy. The survivin inhibitor YM155 induced cell death through autophagy $(26,29,30)$; when mRNA and protein expression levels of survivin and BCL-2 decreased, the expression levels of caspase-3, poly(ADP-ribose) polymerase (PARP), Beclin 1 and LC-3 increased (31). Survivin may also enhance DNA repair capability by upregulating $\mathrm{Ku} 70$ and homologous recombination $(32,33)$.

Urinary bladder cancer (BCa) and kidney cancer are among the most frequently diagnosed cancers and are the leading causes of cancer-related death, ranking sixth and ninth, respectively, in terms of estimated new cases worldwide (34). There have been a number of reports concerning survivin as a tumor marker in the diagnosis of urothelial carcinoma, although further research and confirmation are required. Studies have shown that the serum levels of survivin protein are close to the detection limits of commercial enzyme-linked immunosorbent assay (ELISA) kits (R\&D Systems, Inc., Minneapolis, MN, USA; and Abnova, Taipei, Taiwan) (35). In the present study, using survivin-specific monoclonal antibodies (mAbs) made previously by our laboratory, we aimed to establish methods for detecting the expression of survivin in cancer cell lines, serum samples, urine samples and cancer tissues from $\mathrm{BCa}$ and renal cell carcinoma (RCC) patients, and to further evaluate the efficacy of survivin as a tumor marker in the surveillance of $\mathrm{BCa}$ and $\mathrm{RCC}$.

\section{Materials and methods}

Chemical reagents. Protein-A/G Sepharose (HiTrap Protein G $\mathrm{HP}, 1 \mathrm{ml}$ ) was purchased from GE Healthcare Life Sciences (Little Chalfont, UK). The enhanced chemiluminescence western blotting system and bicinchoninic acid protein assay kit were obtained from Thermo Fisher Scientific, Inc. (Waltham, MA, USA). Horseradish peroxidase (HRP) (H1759) and the IgG Subclass kit were purchased from Sigma-Aldrich (Merck KGaA, Darmstadt, German). 3,3',5,5'-Tetramethylbenzidine (TMB) and ELISA stop buffer were obtained from Cell Signaling Technology, Inc. (Danvers, MA, USA). Phosphate-buffered saline (PBS), HRP-conjugated goat anti-mouse IgG and the immunohistochemistry detection system were purchased from ZSGB-BIO (Beijing, China). PBST (0.05\% Tween-20 in PBS) was used as ELISA washing buffer, Tris-buffered saline (TBS) $(20 \mathrm{mM}$ Tris- $\mathrm{HCl}, \mathrm{pH} 7.5,150 \mathrm{mM} \mathrm{NaCl})$ and TBST $(0.05 \%$ Tween-20 in TBS) were used as western blotting washing buffer.

Cell lines. The lung cancer cell line A549, esophageal carcinoma cell line EC109 and human hepatoblastoma cell line HepG2 were maintained in our laboratory. The BCa cell line 5637 was purchased from the Cell Bank of the Chinese Academy of Sciences (Beijing, China). A549, EC109 and HepG2 cells were cultured in Dulbecco's modified Eagle's medium (DMEM) supplemented with $10 \%$ fetal bovine serum. The 5637 cells were cultured in RPMI-1640 supplemented with $10 \%$ fetal bovine serum.

Animals. The animal experiments were approved by the Animal Care Committee of Peking University and conformed to the guidelines of the National Institutes of Health. All efforts were made to minimize animal suffering. Balb/c mice weighing 18-22 $\mathrm{g}$ were purchased from the Laboratory Animal Centre of the Chinese Academy of Medical Sciences.

Human specimen collection. All human specimens were obtained from Peking University Cancer Hospital and Institute, diagnosed histopathologically, and staged according to the tumor-node-metastasis (TNM) classification released by the American Joint Committee on Cancer (AJCC, 7th edition, 2010). A total of 105 and 125 urine samples, and 122 and 208 corresponding serum samples from BC and RCC patients, respectively, were collected between March 2015 and December 2015. A total of 10 cases of formalin-fixed paraffin-embedded $\mathrm{BCa}$ tissue sections corresponding to the urine samples were also obtained. The healthy control (HC) groups included 131 urine samples and 198 serum samples from individuals who were health-check examinees and showed no abnormalities on laboratory examinations. On the day of collection, all urine samples were centrifuged at $3,000 \mathrm{rpm}$ for $5 \mathrm{~min}$, and the supernatant was acquired, aliquoted and frozen at $-20^{\circ} \mathrm{C}$ until detection. Each patient and healthy examinee signed an informed consent form. All study procedures were in accordance with the Helsinki Declaration and the study was approved by the Ethics Committee of Peking University Cancer Hospital and Institute.

Antibodies and standard protein. Hybridomas (A6, D8, C6, A9 and E6) were prepared previously. Culture supernatants of hybridomas were assessed for survivin expression, immunoglobulin subclass and specificity by ELISA as described below. Hybridoma cells with high signals on ELISA were injected into the abdominal cavity of Balb/c mice. mAbs from the ascites fluids of Balb/c mice were purified by protein $\mathrm{G}$ affinity chromatography. The titer of the purified $\mathrm{mAb}$ was measured using the ELISA method. Antibody concentrations were determined by measuring the absorbance at $280 \mathrm{~nm}$ using BSA as a protein standard. A recombinant human sequence survivin protein, $\mathrm{MS}_{2}$-survivin, produced by our laboratory was used as a protein standard $(36,37)$.

ELISA for the expression in hybridoma supernatants and titer of purified mAbs. Microplates (Costar; Corning Inc., Corning, NY, USA) were coated with $100 \mu 1 \mathrm{MS}_{2}$-survivin proteins $(2.5 \mu \mathrm{g} / \mathrm{ml})$ per well overnight at $4^{\circ} \mathrm{C}$, and then washed 3 times and blocked with $200 \mu \mathrm{l} 5 \%$ skimmed milk for $1 \mathrm{~h}$ at $37^{\circ} \mathrm{C}$. After three washes, $100 \mu 1$ serially diluted hybridoma supernatants (from 1:100, for the expression of mAbs) or $100 \mu \mathrm{l}$ serially diluted purified $\mathrm{mAbs}$ (from 1:1,000, for the titer of $\mathrm{mAbs}$ ) were incubated for $1 \mathrm{~h}$ at $37^{\circ} \mathrm{C}$. Following three washes, $100 \mu 1$ HRP-conjugated goat anti-mouse $\operatorname{IgG}(1: 4,000$ dilution) was used as the secondary antibody. Plates were incubated for another $1 \mathrm{~h}$ at $37^{\circ} \mathrm{C}$, washed 3 times, and $100 \mu 1$ substrate solution TMB was added. The reaction was stopped with $50 \mu \mathrm{l}$ 
stop solution for $20 \mathrm{~min}$ at $37^{\circ} \mathrm{C}$, and the absorbance was then measured at $450 \mathrm{~nm}$ using a microplate reader (model 680; Bio-Rad Laboratories, Inc., Hercules, CA, USA).

ELISA for the specificity and subclass of $m A b s$. As described for the ELISA above, microplates were coated with $100 \mu \mathrm{l}$ $2.5 \mu \mathrm{g} / \mathrm{ml} \mathrm{MS}_{2}$-survivin, GST-survivin, GST-uPA, $\mathrm{MS}_{2}$-PAI, $\mathrm{MS}_{2}-\mathrm{NSE}, \mathrm{MS}_{2}-\mathrm{MK}$ or BSA overnight at $4^{\circ} \mathrm{C}$. Following blocking, hybridoma supernatants diluted 10-fold were added, and HRP-conjugated anti-mouse IgG was used as the secondary antibody. The subclass of the mAbs was identified in the hybridoma supernatants with the mouse mAb isotyping kit (Sigma-Aldrich; Merck KGaA).

Labeling of $m A$ bs with HRP. Anti-survivin mAbs that produced high signals on ELISA (D8, C6, A9 and E6) were selected for labeling with HRP. mAbs were dialyzed against several changes of carbonate buffer [0.1 M sodium carbonate buffer $\left(\mathrm{NaHCO}_{3} / \mathrm{Na}_{2} \mathrm{CO}_{3}\right) \mathrm{pH}$ 9.5] overnight at $4^{\circ} \mathrm{C}$. HRP protein was dissolved in deionized water immediately prior to use (protecting solution from light, stirring for $20 \mathrm{~min}$ at room temperature) at a concentration of $5 \mathrm{mg} / \mathrm{ml}$, and dialyzed against $\mathrm{CH}_{3} \mathrm{COONa}$ $\left(1 \mathrm{mmol} / \mathrm{l}\right.$ sodium acetate buffer, $\mathrm{pH} 4$.4)overnight at $4^{\circ} \mathrm{C} . \mathrm{mAb}$ and HRP solutions were combined in equal quantities by gentle stirring, and incubated at room temperature for $2 \mathrm{~h}$. Next, $0.1 \mathrm{ml}$ $\mathrm{NaH}_{4} \mathrm{~B}$ (sodium borohydride) was added and incubated at $4{ }^{\circ} \mathrm{C}$ for $2 \mathrm{~h}$. The reaction solution was dialyzed against several changes of PBS buffer (0.01 M sodium phosphate, $0.15 \mathrm{M}$ sodium chloride, $\mathrm{pH} 7.4$ ) overnight at $4^{\circ} \mathrm{C}$. After dialyzing, the reaction mixture was applied to a Sephacryl S-200 column to remove uncoupled HRP (38). The mAbs coupled with HRP were used in the subsequent experiments.

Development of a sandwich ELISA using a pair of mAbs. D8, C6, A9 and E6 $(100 \mu \mathrm{l}, 2.5 \mu \mathrm{g} / \mathrm{ml})$ were coated on 96-well microplates overnight at $4^{\circ} \mathrm{C}$. After blocking with $200 \mu \mathrm{l}$ $5 \%$ skimmed milk in PBS for $1 \mathrm{~h}$ at $37^{\circ} \mathrm{C}$ and three washes with PBST, $100 \mu \mathrm{l} 0.5 \mu \mathrm{g} / \mathrm{ml} \mathrm{MS}_{2}$-survivin was added to the corresponding wells. After washing, 1,000- and 5,000-fold diluted HRP-labeled mAbs (D8, C6, A9 and E6) were added. The plates were incubated for $1 \mathrm{~h}$ at $37^{\circ} \mathrm{C}$, washed 3 times and substrate solution was added. The absorbance was measured at $450 \mathrm{~nm}$ after the addition of stop solution. A pair of mAbs was selected to develop a sandwich ELISA system, which was evaluated according to intra-assay precision, inter-assay precision and minimum detectable dose (MDD). By replicating assays in 20 wells with $10 \mathrm{ng} / \mathrm{ml}$ survivin protein as a standard substance, the intra-assay coefficient of variation (CV) was obtained. The inter-assay CV was obtained by detecting the same concentration of survivin protein 10 times.

Detection of the survivin protein with the sandwich ELISA. Using the developed sandwich ELISA system, serum and urine samples from patients and HCs were assessed for survivin expression. Serially diluted $\mathrm{MS}_{2}$-survivin $(2,000-0.24 \mathrm{ng} / \mathrm{ml})$ was detected as a standard, with $0 \mathrm{ng} / \mathrm{ml}$ as blank, and $500 \mathrm{ng} / \mathrm{ml}$ BSA as a negative contrast.

Western blotting. A549, EC109, HepG2 and 5637 cells were harvested, washed twice in ice-cold PBS and lysed using
TPEB extraction reagent (Tiangen Biotech Co., Ltd., Beijing, China) for $30 \mathrm{~min}$ on ice with sonication every $10 \mathrm{~min}$, after which the lysed mixture was separated by centrifugation at $14,000 \times \mathrm{g}\left(4^{\circ} \mathrm{C}\right)$. The supernatants were used as cell lysates. Protein concentration was determined with a bicinchoninic acid protein assay kit. Cell lysates were boiled in lysis buffer containing $2 \% \mathrm{SDS}$ for $10 \mathrm{~min}$. $\mathrm{MS}_{2}$-survivin fusion proteins $(10 \mathrm{ng})$ or cell lysates $(30 \mu \mathrm{g})$ were concentrated by $5 \%$ SDS-PAGE (pH 6.8) at $60 \mathrm{~V}$ for $30 \mathrm{~min}$, fractionated by $12 \%$ SDS-PAGE $(\mathrm{pH} 8.8)$ at $100 \mathrm{~V}$ for $\sim 2 \mathrm{~h}$ and transferred to nitrocellulose membranes at $200 \mathrm{~mA}$ for $1.5 \mathrm{~h}$. Western markers (Beijing Transgen Biotech Co., Ltd., Beijing, China) were run in parallel. The blotted membranes were blocked with $5 \%$ non-fat milk in PBST and incubated overnight at $4{ }^{\circ} \mathrm{C}$ with enzyme-linked mAbs; anti-survivin mAb D8 (sc-17779; Santa Cruz Biotechnology, Inc., Dallas, TX, USA) was used as a positive control. After washing, the HRP-conjugated goat anti-mouse IgG was used as the secondary antibody for D8 (Santa Cruz Biotechnology, Inc.) and incubated for $1 \mathrm{~h}$ at room temperature. Following three washes with PBST, bound antibodies were visualized using enhanced chemiluminescence. For normalization of the target gene, $\beta$-actin was used as an internal reference.

Immunohistochemistry. Paraffin sections of 4- $\mu \mathrm{m}$ thickness were baked for $2 \mathrm{~h}$ at $65^{\circ} \mathrm{C}$. Deparaffinization was performed using xylene (15 min, twice) and hydration was conducted using a series of graded ethanol $(100,95,85$ and $75 \% ; 5$ min each) to distilled water. The antigens were retrieved with $\mathrm{pH} 6.0$ citrate buffer for $5 \mathrm{~min}$ at $125^{\circ} \mathrm{C}$ in a pressure boiler. Following cooling and washing with PBST, blocking for endogenous peroxidase was performed for $10 \mathrm{~min}$ in $0.3 \% \mathrm{H}_{2} \mathrm{O}_{2}$. After three further washes in PBST, non-specific binding was blocked with PBST containing 5\% skimmed milk for $30 \mathrm{~min}$ at room temperature. The sections were then rinsed in PBST 3 times and incubated at $4^{\circ} \mathrm{C}$ with mAbs, anti-survivin mAb D8 (Santa Cruz Biotechnology, Inc.) as a positive control, or 5\% skimmed milk in PBST as negative control. Following three washes, the sections were incubated with Polymer Helper for $20 \mathrm{~min}$, and then washed again 3 times prior to incubation for $30 \mathrm{~min}$ with polyperoxidase-anti-mouse/rabbit IgG. After a further three washes, the sections were sequentially developed in DAB solution for $5 \mathrm{~min}$, counterstained in hematoxylin for $1 \mathrm{~min}$, washed in tap water, rinsed in ethanol containing $1 \%$ hydrochloric acid, washed in tap water for $30 \mathrm{~min}$, and dehydrated in graded ethanol $(75,85,95$ and $100 \%)$ and xylene. Coverslips were applied to the samples, which were then evaluated under light microscopy independently by two pathologists from the Department of Pathology, Peking University Cancer Hospital and Institute, without prior knowledge of the patient clinical data. The intensity of the staining was scored on a scale of no staining/negative, weak staining $/(+)$, moderate staining $/(++)$ and strong staining/(+++).

Statistical analysis. Statistical analysis was carried out using SPSS for Windows (version 16.0; SPSS, Inc., Chicago, IL, USA). The survivin concentrations in patients and healthy individuals were compared by Student's t-test and also assessed using the area under the receiver operating characteristic (ROC) curve (AUC). The cut-off value was determined 

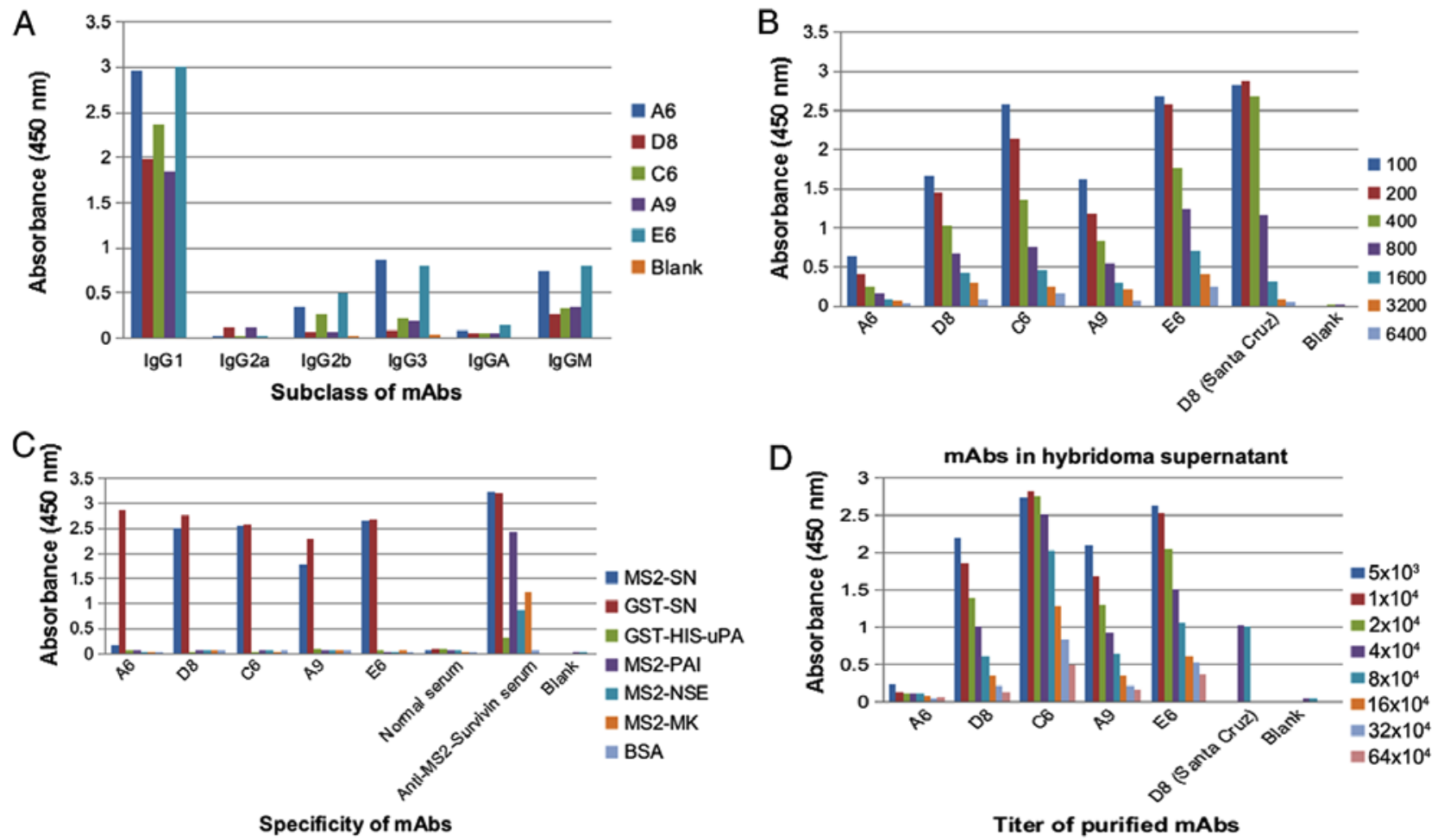

Titer of purified mAbs

Figure 1. Characterization of survivin mAbs. ELISA for (A) the subclass of mAbs, (B) the expression of mAbs in hybridoma supernatants, (C) the specificity of $m A b s$ and $(D)$ the titer of purified mAbs. mAbs, monoclonal antibodies.
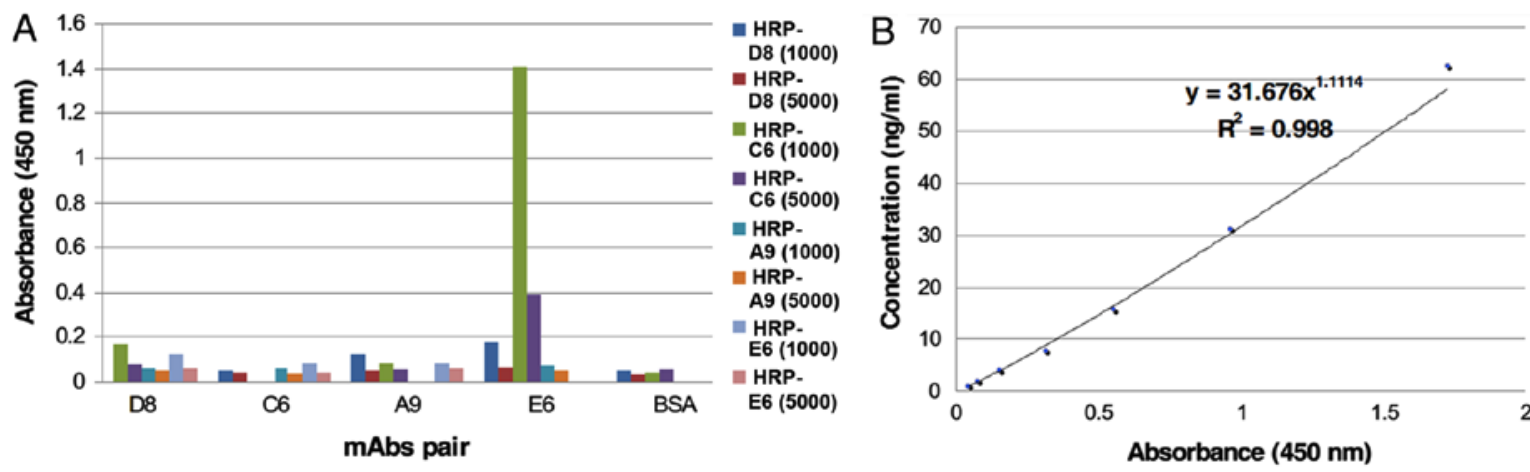

Figure 2. Development of sandwich ELISA. (A) D8, C6, and E6 were used as the coating antibodies, while the corresponding enzyme-linked mAbs HRP-D8, HRP-C6 and HRP-E6 were used as the detecting antibodies, respectively, to develop a sandwich ELISA. E6 was selected as the capturing mAb and HRP-C6 as the detecting mAb. (B) Standard curve. Serially diluted $\mathrm{MS}_{2}$-survivin $(2,000-0.98 \mathrm{ng} / \mathrm{ml})$ was detected to establish the standard curve. $\mathrm{mAbs}$, monoclonal antibodies; HRP, horseradish peroxidase.

by the optimal Youden's index (sensitivity + specificity - 1). All tests were two-sided and $\mathrm{P}<0.05$ was set as the significance level.

\section{Results}

Expression, specificity, titer and subclass of $m A b s$. Hybridomas were tested for survivin subclass by indirect ELISA. Hybridomas (A6, D8, C6, A9 and E6) with high expression, specificity and antibody titer were selected for further $\mathrm{mAb}$ pairing. The results showed that the subclass of these mAbs was IgG1 (Fig. 1A). D8, C6, A9 and E6, which exhibited strong signals on ELISA, were chosen for subsequent $\mathrm{mAb}$ pairing (Fig. 1B-D).
Sandwich ELISA development and evaluation. E6 was selected as the capture mAb and HRP-C6 was selected as the detecting $\mathrm{mAb}$ to develop the sandwich ELISA (Fig. 2A). The intra-assay CV was $7.28 \%$ and the inter-assay CV was $9.58 \%$, indicating that the sandwich ELISA had good reproducibility. According to the standard protein curve (Fig. 2B), the MDD of the assay was $0.98 \mathrm{ng} / \mathrm{ml}$.

Expression levels of survivin in urine and serum samples from patients. Urine samples from 105 cases of $\mathrm{BCa}$ and 125 cases of RCC, as well as 122 and 208 corresponding serum samples, were assessed. The HC groups included 131 urine samples and 198 serum samples from health-check examinees who showed no abnormalities on laboratory examination results. The basic 

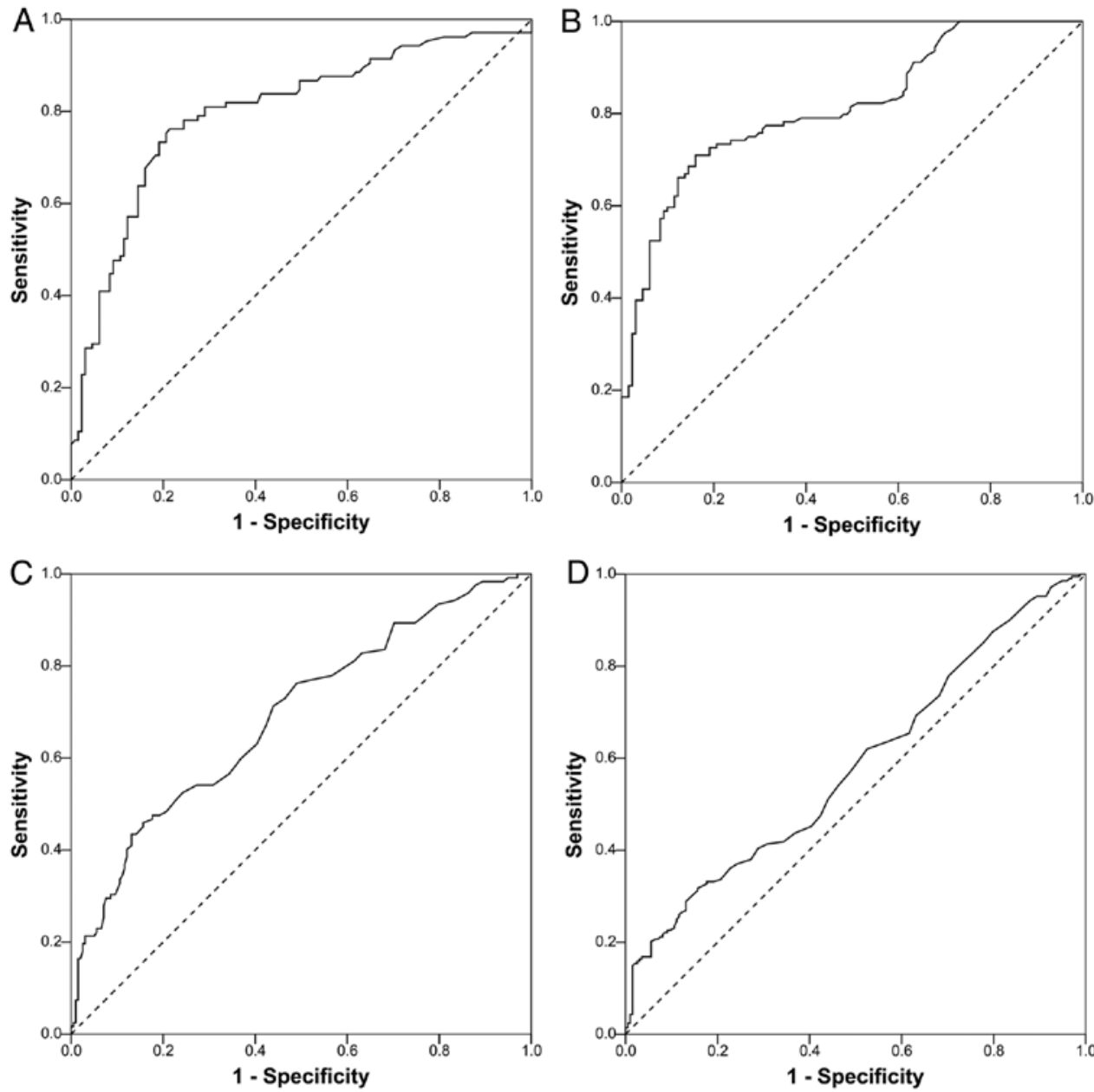

Figure 3. ROC curves based on the detection of survivin in urine and serum among cancer patients and HCs. (A) The area under the ROC curve (AUC) was 0.800 in urine from BCa patients. (B) The AUC was 0.812 in urine from RCC patients. (C) The AUC was 0.691 in serum from BCa patients. (D) The AUC was 0.600 in serum from RCC patients. ROC, receiver operating characteristic; HCs, healthy controls; BCa, bladder cancer; RCC, renal cell carcinoma.

characteristics, including the age and sex of the patients and HCs, are summarized in Table I.

In $\mathrm{BCa}$ and RCC patients, survivin concentrations were significantly higher compared with those in HCs in both the urinary and serum samples $(\mathrm{P}<0.05)$ (Table II).

ROC curves based on the detection of survivin in urine and serum samples from cancer patients and HCs are shown in Fig. 3. The AUCs were 0.800, 0.812, 0.691 and 0.600, respectively, in $\mathrm{BCa}$ urine, $\mathrm{RCC}$ urine, $\mathrm{BCa}$ serum and $\mathrm{RCC}$ serum samples. According to the optimal Youden's index, cut-off values of 8.2765 and $9.4985 \mathrm{ng} / \mathrm{ml}$ in urine samples were proposed for $\mathrm{BCa}$ and $\mathrm{RCC}$, respectively, corresponding to sensitivity values of 76.20 and $71.00 \%$, and specificity values of 88.60 and $84.00 \%$. In BCa and RCC serum samples, cut-off values of 1.2385 and $1.1625 \mathrm{ng} / \mathrm{ml}$, respectively, resulted in sensitivity values of 71.3 and $62.00 \%$, and specificity values of 56.10 and $47.50 \%$ (Table II). The scatter plot showing the survivin concentrations in samples from BCa and RCC patients and HCs is shown in Fig. 4.

Survivin concentrations higher than the cut-off value were defined as positive. Among the 50 positive urine samples from patients with $\mathrm{BCa}, 39$ (78\%) of their corresponding serum samples were also positive, while in RCC, 27 serum samples $(41.54 \%)$ were positive out of the 65 patients with positive urine
Table I. Basic characteristics (age and sex) of the $\mathrm{BCa}$ and RCC patients and HCs.

\begin{tabular}{lccrr}
\hline & & & \multicolumn{2}{c}{ Sex } \\
\cline { 4 - 5 } Samples & $\mathrm{N}$ & $\begin{array}{c}\text { Age in years } \\
{[\text { mean (range) }}\end{array}$ & Male & Female \\
\hline Healthy urine & 131 & $48.1679(24-66)$ & 108 & 23 \\
Healthy serum & 198 & $36.9141(22-66)$ & 69 & 129 \\
BCa urine & 105 & $61.8544(29-84)$ & 71 & 34 \\
BCa serum & 122 & $62.1721(29-81)$ & 96 & 26 \\
RCC urine & 124 & $57.0000(24-85)$ & 83 & 31 \\
RCC serum & 208 & $57.1394(27-84)$ & 132 & 76 \\
\hline
\end{tabular}

BCa, bladder cancer; RCC, renal cell carcinoma; HCs, healthy controls.

samples. This indicated that survivin concentration in urine was fairly consistent with that in serum. No significant differences in the expression of survivin were observed between patients with primary and recurrent BCa (Tables III and V). Before and after surgery, survivin concentration also showed no significant differences in BCa or RCC patients (Tables III-VI). 
Table II. Survivin level in BCa and RCC patients and HCs in both urinary and serum samples.

\begin{tabular}{|c|c|c|c|c|c|c|}
\hline Samples (n) & $\begin{array}{l}\text { Survivin level } \\
(\text { mean } \pm S D)\end{array}$ & P-value & AUC & Cut-off value & Sensitivity & Specificity \\
\hline \multicolumn{7}{|c|}{ Urine samples } \\
\hline $\mathrm{HC}(131)$ & $28.7327 \pm 75.56408$ & & & & & \\
\hline $\mathrm{BCa}(105)$ & $131.1819 \pm 150.13326$ & $<0.001$ & 0.800 & 8.2765 & 0.762 & 0.886 \\
\hline $\mathrm{RCC}(124)$ & $173.4632 \pm 161.66956$ & $<0.001$ & 0.812 & 9.4985 & 0.71 & 0.84 \\
\hline \multicolumn{7}{|c|}{ Serum samples } \\
\hline $\mathrm{HC}(198)$ & $1.6221 \pm 3.45691$ & & & & & \\
\hline $\mathrm{BCa}(122)$ & $3.4660 \pm 8.78510$ & 0.009 & 0.691 & 1.2385 & 0.713 & 0.561 \\
\hline RCC (208) & $2.8443 \pm 7.12991$ & 0.028 & 0.600 & 1.1625 & 0.620 & 0.475 \\
\hline
\end{tabular}

P-values in bold print indicate significant difference. BCa, bladder cancer; RCC, renal cell carcinoma; HCs, healthy controls.
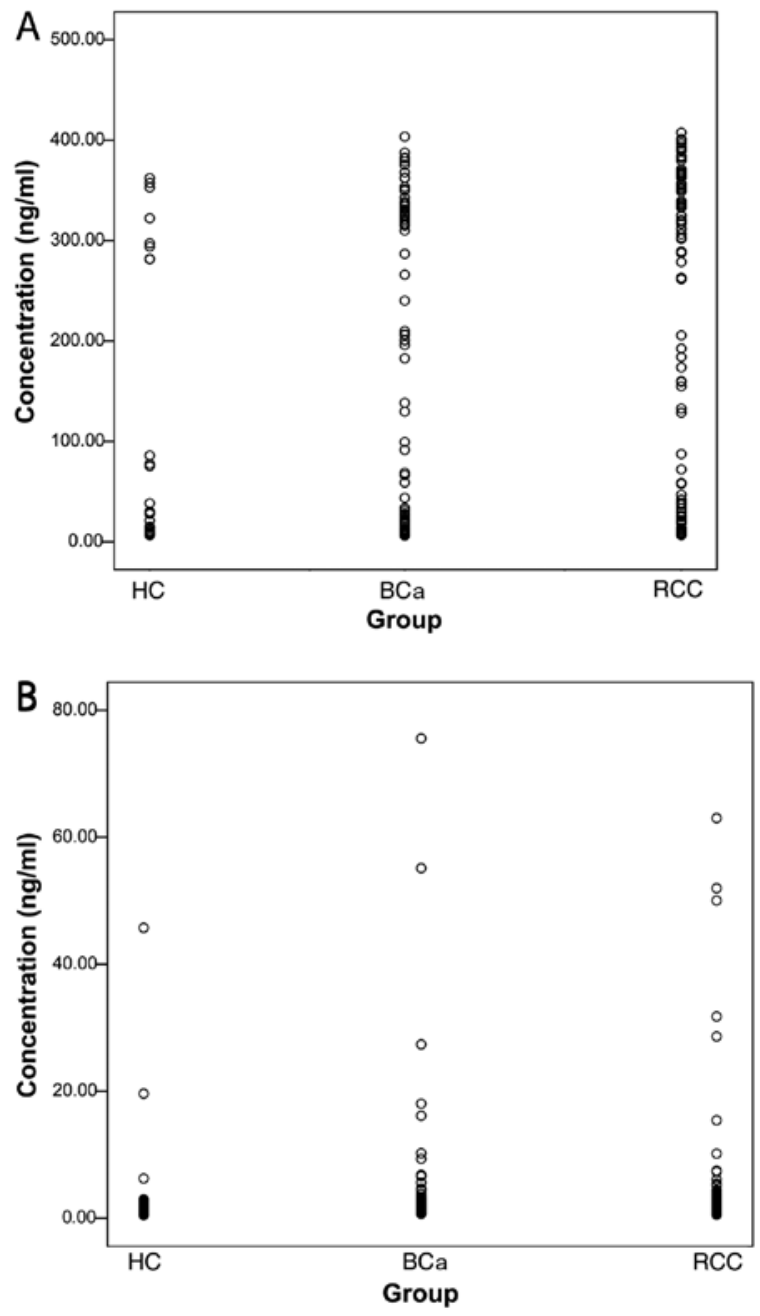

Figure 4. Scatter plots of survivin expression in BCa and RCC patients and HCs. (A) Survivin concentration in urine samples of $105 \mathrm{BCa}$ patients, $125 \mathrm{RCC}$ patients and $131 \mathrm{HC}$. (B) Survivin concentration in serum samples of $122 \mathrm{BCa}$ patients, $208 \mathrm{RCC}$ patients and $198 \mathrm{HC}$. BCa, bladder cancer; RCC, renal cell carcinoma; HCs, healthy controls.

The associations between the expression of survivin and the clinicopathological characteristics of BCa and RCC patients were analyzed by Student's t-test. No associations

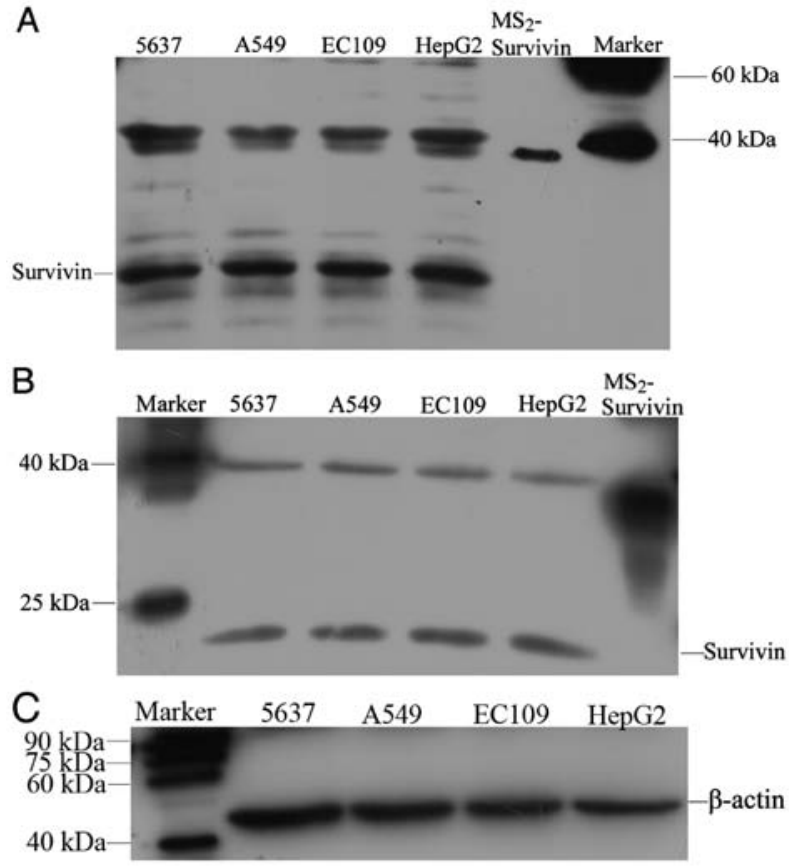

Figure 5. Western blotting of survivin expression in cancer cell lines. Expression of survivin in cancer cell lines as detected with (A) enzyme-linked mAbs (HRP-mAbs) and (B) the D8 antibody (Santa Cruz Biotechnology, Inc.). (C) $\beta$-actin was used as the internal reference. mAbs, monoclonal antibodies; HRP, horseradish peroxidas.

were identified, except association between hypertension and the presence of survivin in the serum of RCC patients was found $(\mathrm{P}=0.012)$ (Tables III-VI).

In addition, previous studies have reported on the use of nuclear matrix protein 22 (NMP22) in the diagnosis of $\mathrm{BCa}(39,40)$. In the present study, no association between NMP22 and survivin level was found (Table III).

Expression of survivin in cancer cell lines. Western blotting was applied to determine whether survivin was expressed in cancer cell lines and whether the HRP-conjugated mAbs produced in the present study could be used to detect survivin. The western blotting results indicated that standard $\mathrm{MS}_{2}$-survivin was detectable as a $30-\mathrm{kDa}$ band, while survivin 
Table III. Correlation between the level of survivin in urine and clinicopathological characteristics of the BCa patients.

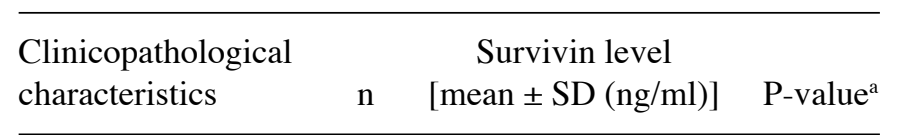

Sex

Male

Female

68

$147.533 \pm 150.6453$

0.2308

34

$109.4359 \pm 150.0653$

Age (years)

$\leq 60$

$44 \quad 131.6626 \pm 158.9245$

$>60$

$58 \quad 137.2398 \pm 145.6814$

Tumor number

1

$\geq 2$

36

29

$134.1215 \pm 151.2537$

$143.405 \pm 156.5502$

Tumor size (mm)

$\leq 30$

48

$152.9562 \pm 156.843$

$>30$

25

$127.7777 \pm 149.2811$

Primary or not

Primary

Recurrent

70

27

$139.0455 \pm 154.1364$

$129.2186 \pm 143.5481$

Primary

Preoperation

29

$131.741 \pm 160.0746$

41

$144.212 \pm 151.591$

Recurrent

Preoperation

Postoperation

\section{8}

$181.713 \pm 144.7057$

$115.344 \pm 147.2315$

Tumor grade

$$
\text { G1-G2 }
$$

G3

$151.8126 \pm 156.8784$

$129.7054 \pm 151.0077$

Tumor thrombus

\begin{tabular}{lccc} 
Visible & 12 & $116.5475 \pm 126.4072$ & 0.4722 \\
Invisible & 23 & $155.526 \pm 161.2349$ & \\
Nodal status & & & \\
Positive & 14 & $102.4099 \pm 141.4549$ & 0.4438 \\
Negative & 91 & $135.6084 \pm 151.6818$ & \\
Tumor stage & & & \\
<pT2 & 25 & $170.8168 \pm 167.305$ & 0.1397 \\
>pT2 & 50 & $116.1421 \pm 139.9187$ & \\
TNM stage & & & \\
I-II & 27 & $155.4603 \pm 161.8041$ & 0.2152 \\
III-IV & 32 & $107.7036 \pm 130.888$ & \\
NPM22 & & & \\
Positive & 14 & $154.2549 \pm 166.2502$ & 0.7092 \\
Negative & 29 & $174.1876 \pm 161.573$ & \\
Smoking status & & & \\
Yes & 33 & $164.6349 \pm 159.3603$ & 0.2442 \\
No & 56 & $125.2063 \pm 149.5392$ & \\
Hypertension & & & \\
Yes & 37 & $151.438 \pm 160.473$ & 0.5581 \\
No & 52 & $131.9741 \pm 149.1533$ & \\
\hline & & & \\
\hline
\end{tabular}

aAnalyzed by Student's t-test. BCa, bladder cancer; TNM, tumor-node-metastasis; NMP22, nuclear matrix protein 22.
Table IV. Correlation between the level of survivin in urine and the clinicopathological characteristics of the RCC patients.

\begin{tabular}{|c|c|c|c|}
\hline $\begin{array}{l}\text { Clinicopathological } \\
\text { characteristics }\end{array}$ & $\mathrm{n}$ & $\begin{array}{c}\text { Survivin level } \\
{[\text { mean } \pm \mathrm{SD}(\mathrm{ng} / \mathrm{ml})]}\end{array}$ & P-value \\
\hline \multicolumn{4}{|l|}{ Sex } \\
\hline Male & 82 & $178.5686 \pm 160.1717$ & 0.7175 \\
\hline Female & 41 & $167.3186 \pm 166.2319$ & \\
\hline \multicolumn{4}{|l|}{ Age (years) } \\
\hline$\leq 60$ & 31 & $144.4049 \pm 162.146$ & 0.2272 \\
\hline$>60$ & 92 & $185.0668 \pm 161.0323$ & \\
\hline \multicolumn{4}{|l|}{ TNM stage } \\
\hline I-II & 76 & $202.8524 \pm 165.8122$ & 0.108 \\
\hline III-IV & 48 & $202.8524 \pm 151.951$ & \\
\hline \multicolumn{4}{|l|}{ Fuhrman grade } \\
\hline I-II & 55 & $158.7662 \pm 163.3089$ & 0.2007 \\
\hline III-IV & 31 & $205.2525 \pm 155.3374$ & \\
\hline \multicolumn{4}{|l|}{ Histologic category } \\
\hline Clear cell & 89 & $179.8389 \pm 159.4347$ & 0.6202 \\
\hline Other & 29 & $162.6501 \pm 168.9348$ & \\
\hline \multicolumn{4}{|l|}{ Tumor size (mm) } \\
\hline$\leq 50$ & 54 & $157.3316 \pm 163.8723$ & 0.113 \\
\hline$>50$ & 42 & $209.9445 \pm 154.5213$ & \\
\hline \multicolumn{4}{|l|}{ Tumor thrombus } \\
\hline Visible & 14 & $135.9681 \pm 168.2002$ & 0.2291 \\
\hline Invisible & 71 & $193.1823 \pm 160.2078$ & \\
\hline \multicolumn{4}{|l|}{ Smoking status } \\
\hline Yes & 35 & $164.2389 \pm 154.3379$ & 0.3223 \\
\hline No & 73 & $197.3422 \pm 165.3699$ & \\
\hline \multicolumn{4}{|l|}{ Hypertension } \\
\hline Yes & 38 & $178.8563 \pm 159.3798$ & 0.7155 \\
\hline No & 70 & $190.8257 \pm 164.2466$ & \\
\hline
\end{tabular}

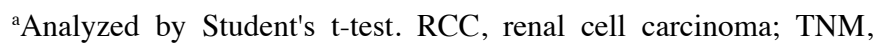
tumor-node-metastasis.

in the cell lines was observed as a $16.5-\mathrm{kDa}$ band and $\beta$-actin as a 42-kDa band (Fig. 5C). 5637, A549, EC109 and HepG2 cells all expressed survivin, and the positive signals detected by the HRP-conjugated $\mathrm{mAb}$ (Fig. 5A) were consistent with those detected by the commercial D8 antibody (Santa Cruz Biotechnology, Inc.) (Fig. 5B). In addition, bands at $30-40 \mathrm{kDa}$ were present in all of the cell lines with both mAbs, which may represent heterodimers or aggregates of survivin (Fig. 5A and B).

Survivin expression in human BCa tissue. In order to verify that survivin mAbs could identify survivin expression in human tissues, immunohistochemistry was used to detect survivin expression in BCa tissue, with the D8 antibody (Santa Cruz Biotechnology, Inc.) used as a control. Among $10 \mathrm{BCa}$ samples, all samples displayed positive staining of survivin protein in the cancer cells at different expression levels using both the survivin mAbs and the D8 antibody (Santa Cruz 
Table V. Corrrelation between the level of survivin in serum and the clinicopathological characteristics of the $\mathrm{BCa}$ patients.

\begin{tabular}{llccc}
\hline $\begin{array}{l}\text { Clinicopathological } \\
\text { characteristics }\end{array}$ & \multicolumn{3}{c}{$\begin{array}{c}\text { Survivin level } \\
{[\text { mean } \pm \mathrm{SD}(\mathrm{ng} / \mathrm{ml})]}\end{array}$} & P-value $^{\mathrm{a}}$
\end{tabular}

\section{Sex}

Male

Female

$96 \quad 3.696406 \pm 9.550458$

0.5799

Age (years)

$$
\leq 60
$$

$>60$

$51 \quad 2.582745 \pm 2.824331$

$71 \quad 4.100479 \pm 11.25758$

Tumor number

$$
1
$$

$\geq 2$

$$
\begin{array}{ll}
46 & 4.352109 \pm 11.68199 \\
44 & 2.414568 \pm 2.853097
\end{array}
$$

Tumor size (mm)

$\leq 30$
$>30$

$65 \quad 3.578169 \pm 9.72505$

$37 \quad 2.277784 \pm 2.857489$

Primary or not

Primary

Recurrent

$$
\begin{array}{lr}
95 & 3.238726 \pm 9.413477 \\
24 & 4.5705 \pm 6.482018
\end{array}
$$

Primary

Preoperation
Postoperation

Tumor grade

$\begin{array}{llr}\text { G1-G2 } & 20 & 6.2087 \pm 16.74663 \\ \text { G3 } & 91 & 2.483747 \pm 3.440776\end{array}$

Tumor thrombus

$\begin{array}{llcl}\text { Visible } & 19 & 3.250842 \pm 3.698517 & 0.1065 \\ \text { Invisible } & 26 & 1.769385 \pm 1.140501 & \\ \text { Nodal status } & & & \\ \quad \text { Positive } & 21 & 2.638762 \pm 3.288208 & 0.223 \\ \text { Negative } & 18 & 1.716389 \pm 0.6870672 & \\ \text { Tumor grade } & & & \\ \text { <pT2 } & 24 & 2.504208 \pm 5.329035 & 0.5181 \\ \geq \mathrm{pT} 2 & 70 & 3.5015 \pm 9.065315 & \\ \text { TNM stage } & & & \\ \text { I-II } & 61 & 3.486115 \pm 10.05631 & 0.2152 \\ \text { III-IV } & 35 & 2.697457 \pm 2.812385 & \\ \text { Smoking status } & & & \\ \text { Yes } & 42 & 2.236857 \pm 3.004294 & 0.2349 \\ \text { No } & 71 & 3.682845 \pm 9.411087 & \\ \text { Hypertension } & & & \\ \text { Yes } & 42 & 2.595571 \pm 4.7085 & 0.5244 \\ \text { No } & 73 & 3.406726 \pm 8.902606 & \\ \end{array}$

aAnalyzed by Student's t-test. BCa, bladder cancer; TNM, tumor-node-metastasis.

Biotechnology, Inc.). The results revealed that survivin was

\begin{tabular}{|c|c|c|c|}
\hline $\begin{array}{l}\text { Clinicopathological } \\
\text { characteristics }\end{array}$ & $\mathrm{n}$ & $\begin{array}{c}\text { Survivin level } \\
{[\text { mean } \pm \mathrm{SD}(\mathrm{ng} / \mathrm{ml})]}\end{array}$ & P-value ${ }^{a}$ \\
\hline \multicolumn{4}{|l|}{ Sex } \\
\hline Male & 132 & $3.238803 \pm 8.425232$ & 0.2117 \\
\hline Female & 76 & $2.159039 \pm 3.945889$ & \\
\hline \multicolumn{4}{|l|}{ Age (years) } \\
\hline$\leq 50$ & 53 & $3.308321 \pm 7.91286$ & 0.5843 \\
\hline$>50$ & 155 & $2.6856 \pm 6.862163$ & \\
\hline \multicolumn{4}{|l|}{ TNM stage } \\
\hline I-II & 63 & $3.338 \pm 9.992344$ & 0.6743 \\
\hline III-IV & 87 & $2.740908 \pm 6.052562$ & \\
\hline \multicolumn{4}{|l|}{ Fuhrman grade } \\
\hline I-II & 109 & $3.31945 \pm 8.594069$ & 0.08494 \\
\hline III-IV & 56 & $1.84625 \pm 1.528992$ & \\
\hline \multicolumn{4}{|l|}{ Histologic category } \\
\hline Clear cell & 24 & $2.77989 \pm 6.906926$ & 0.7456 \\
\hline Other & 172 & $3.211257 \pm 8.32561$ & \\
\hline \multicolumn{4}{|l|}{ Tumor size (mm) } \\
\hline$\leq 50$ & 98 & $3.723214 \pm 9.906343$ & 0.1146 \\
\hline$>50$ & 80 & $2.036437 \pm 3.158853$ & \\
\hline \multicolumn{4}{|l|}{ Tumor thrombus } \\
\hline Visible & 27 & $3.507778 \pm 9.377017$ & 0.5324 \\
\hline Invisible & 139 & $2.951094 \pm 7.665209$ & \\
\hline \multicolumn{4}{|l|}{ Smoking status } \\
\hline Yes & 54 & $2.6185 \pm 3.955068$ & 0.6389 \\
\hline No & 136 & $3.042706 \pm 8.449693$ & \\
\hline \multicolumn{4}{|l|}{ Hypertension } \\
\hline Yes & 68 & $1.542221 \pm 0.9502749$ & 0.01248 \\
\hline No & 128 & $3.605889 \pm 9.051269$ & \\
\hline
\end{tabular}
distributed in the nuclei and cytoplasm of BCa cells, although predominantly in the cell nuclei. The intensity of immunostaining with the survivin mAbs was weak/(+) in 1 case $(10 \%)$,
Table VI. Correlation between the level of survivin in serum and the clinicopathological characteristics of the RCC patients.

P-value in bold print indicates significant difference. ${ }^{a}$ Analyzed by Student's t-test. RCC, renal cell carcinoma; TNM, tumor-node-metastasis.

moderate/(++) in 4 cases $(40 \%)$, and strong $/(+++)$ in 5 cases (50\%) (Fig. 6), whereas $7(70 \%)$ and $3(30 \%)$ cases showed moderate/(++) and strong/(+++) staining, respectively, with the D8 antibody (Santa Cruz Biotechnology, Inc.). The corresponding urine and serum samples of the 1 weak/(+) positive BCa tissue were both negative on ELISA. In the 9 patients with cancer tissues expressing moderate or strong survivin levels, the following results were observed: the serum samples of 4 patients were not collected, while their urine samples were all positive for survivin on ELISA; in 3 of the patients, both urine and serum samples were positive on ELISA; and in the remaining 2 patients, urine samples were positive and serum samples were negative on ELISA.

Further findings suggested a positive correlation between the intensity of immunostaining and tumor grade (G1, G2, G3). Among 4 patients with tumor grade G2, the intensity of immunostaining was weak/(+) in 1 and moderate/(++) in 3 ; 

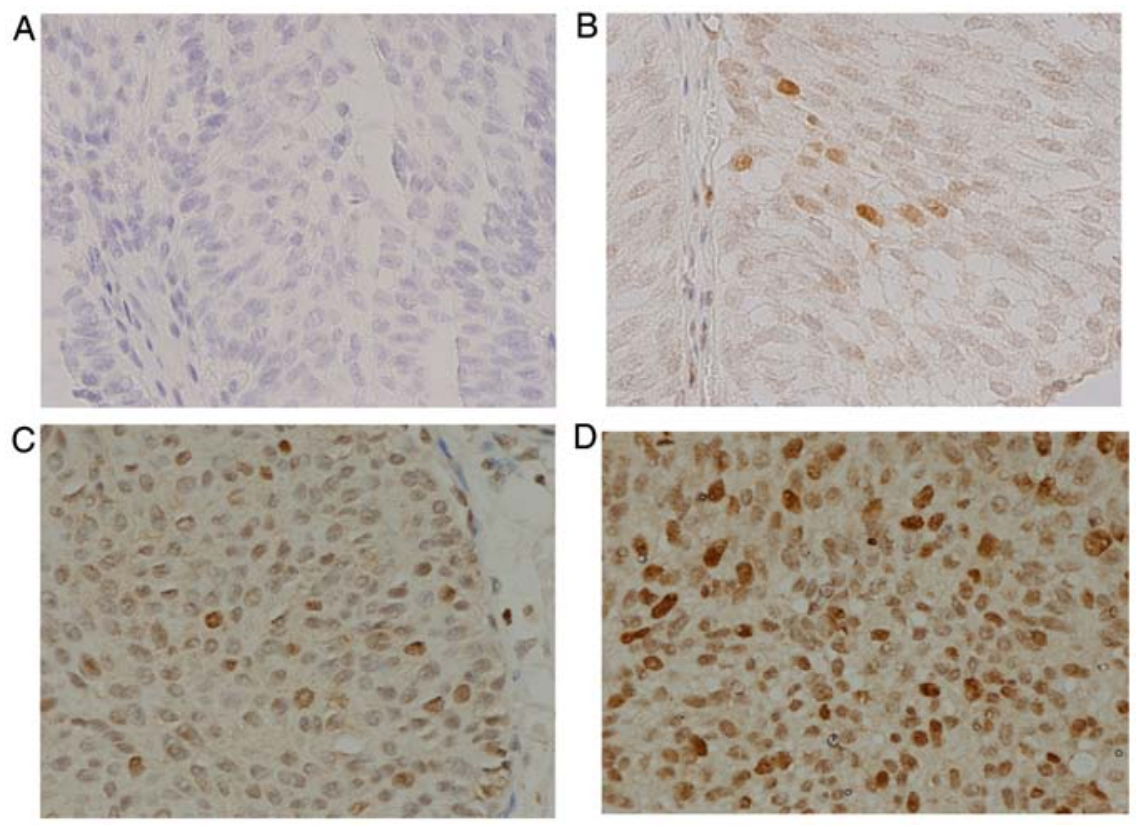

Figure 6. Immunohistochemistry images. (A) Negative control incubated with 5\% skimmed milk in PBST. (B-D) BCa tissue samples showing (B) weak/(+), (C) moderate/(++) and (D) strong/(+++) expression of survivin. Magnification, $\mathrm{x} 40$. BCa, bladder cancer.

whereas, among 6 patients with tumor grade G3, 2 exhibited moderate/(++) and 4 exhibited strong/(+++) immunostaining.

\section{Discussion}

Survivin has been shown to have significance in clinical applications. Recent studies have demonstrated the diagnostic role of survivin in urogenital and urinary bladder cancer (41-43), and survivin overexpression may be an important prognostic factor for recurrence in certain cancers (44-46). Serum survivin levels before and during chemotherapy may serve as a predictive biomarker for the treatment response in malignant mesothelioma (47). Furthermore, studies have also shown that survivin mediates multidrug resistance and reduces apoptosis $(48,49)$. In recent years, a number of studies have focused on targeting survivin as a therapeutic strategy, which has included the use of small-molecule inhibitors and peptidomimetics (YM155, shepherdin) $(50,51)$, transcriptional inhibitors such as survivin antisense oligonucleotides (LY2181308, EZN-3042) $(52,53)$, gene therapy and immunotherapy (54). Many studies have also investigated the mechanism of action of survivin. The BIR domain of survivin interferes with caspase- 3 and -7 and induces inhibition of apoptosis (21). Survivin can interact with the cell cycle regulator $\mathrm{Cdk} 4$, leading to $\mathrm{Cdk} 2 /$ cyclin $\mathrm{E}$ activation and $\mathrm{Rb}$ phosphorylation (55). Survivin overexpression also activates NF- $\kappa \mathrm{B}$ p65, which is important for the acquisition and maintenance of the oncogenic characteristics of cancer (56). In addition, the HER2-STAT3-survivin axis could serve as a predictive marker and therapeutic target to overcome radiotherapy resistance in HER2-positive breast cancer (57). However, further investigations are still required to fully elucidate the role of survivin in different types of cancers.

Previous studies have demonstrated that a detrimental feature of bladder cancer is its high recurrence rate, which necessitates frequent surveillance imaging and repetitive transurethral resections (58). In the present study, using a sandwich ELISA method developed with E6 and HRP-C6 antibodies, survivin expression in both urine and serum samples was demonstrated to be significantly higher in patients with bladder cancer or renal cell carcinoma than that noted in healthy controls, and this difference was more pronounced in urine samples. In both bladder cancer and renal cell carcinoma patients, survivin expression showed no significant differences in primary vs. recurrent cancer or before vs. after surgery. These results implicate survivin as a potential tumor marker for the diagnosis and prognosis of bladder cancer or renal cell carcinoma. In addition, hypertension is a significant risk factor for renal cell carcinoma. Several studies have shown a dose-dependent increase in renal cell carcinoma with increasing blood pressure level $(59,60)$, and the present study demonstrated that the expression of survivin in the serum of renal cell carcinoma patients was associated with hypertension.

It has been shown that different splice variants of survivin give rise to distinct protein isoforms: survivin-2B and survivin- $\Delta \mathrm{Ex} 3$ retain anti-apoptotic activity (8); survivin-3B exerts cytoprotective functions (9); and survivin-2 $\alpha$ is not assumed to exert any anti-apoptotic activity (10). The expression levels of the five survivin splice variants were all significantly higher in cancer tissues compared with these levels in normal tissues in previous studies $(61,62)$. In the present study, western blotting was used to assess survivin expression in the cancer cell lines 5637, A549, EC109 and HepG2. A band at 30-40 kDa was detected using both the HRP-conjugated mAbs generated in our laboratory and the commercial antibody purchased from Santa Cruz; this band was assumed to represent heterodimers or aggregates of survivin. Previous studies have shown that, in the case of wt survivin, $\sim 94 \%$ of wt survivin consisted of dimers containing some monomers, and the remaining $6 \%$ of wt survivin consisted of large aggregates (63). Monomers in mammalian cells can form heterodimers by binding to other proteins, such as CRM1 (63), and survivin splice variants may also heterodimerize with survivin to regulate its functions $(64,65)$. 
Previous studies have shown that survivin localization in cells is consistent with its function in cell division (nucleus) and cell viability (cytoplasm), as well as confirming the presence of different isoforms which had distinct cellular localizations (66). Immunohistochemical analysis in the present study illustrated that survivin was distributed in the nucleus and cytoplasm of bladder cancer cells, although predominantly in the cell nucleus. The expression of survivin in tissues may be consistent with that in urine and serum. Previous studies have found that the presence of nuclear survivin may be an independent biomarker for disease recurrence and overall survival in cancer patients $(67,68)$. In post-chemoradiotherapy tissues, nuclear survivin expression disappeared completely and cytoplasmic expression increased, particularly in treatment-responsive patients (69). A positive correlation between the intensity of immunostaining and tumor grade (G1, G2, G3) was found in the present study, which further confirmed the role of survivin in tumors.

In conclusion, the sandwich ELISA established in the present study had high sensitivity and specificity for the detection of survivin expression. Survivin expression in urine and serum samples from bladder cancer and renal cell carcinoma patients was significantly higher than that in healthy controls. Western blotting of cancer cell lines with HRP-conjugated mAbs and immunohistochemistry of cancer tissues confirmed survivin expression in bladder cancer. Our study further suggests that survivin is a potential tumor marker for the surveillance of bladder cancer and renal cell carcinoma. The availability of these survivin mAbs would be of use in a wide range of studies on survivin.

\section{Acknowledgements}

The authors thank Spandidos Publications for their assistance with language editing of our manuscript.

\section{Funding}

This study was supported by the Capital Laboratory Medicine Clinical Characteristic Fund (no. Z121107005112004).

\section{Availability of data and materials}

The datasets used during the present study are available from the corresponding author upon reasonable request.

\section{Authors' contributions}

QZ conceived and designed the study. DC and JX performed the experiments. DC wrote the paper. QZ and DC reviewed and edited the manuscript. All authors read and approved the manuscript and agree to be accountable for all aspects of the research in ensuring that the accuracy or integrity of any part of the work are appropriately investigated and resolved.

\section{Ethics approval and consent to participate}

All study procedures were in accordance with the Helsinki Declaration and the study was approved by the Ethics Committee of Peking University Cancer Hospital and Institute.
The animal experiments were approved by the Animal Care Committee of Peking University and conformed to the guidelines of the National Institutes of Health.

\section{Consent for publication}

Each patient and healthy examinee provided written informed consent for the publication of any associated data and accompanying images.

\section{Competing interests}

The authors state that they have no competing interests.

\section{References}

1. Ambrosini G, Adida C and Altieri DC: A novel anti-apoptosis gene, survivin, expressed in cancer and lymphoma. Nat Med 3: 917-921, 1997.

2. Deveraux QL and Reed JC: IAP family proteins - suppressors of apoptosis. Genes Dev 13: 239-252, 1999.

3. Miller LK: An exegesis of IAPs: Salvation and surprises from BIR motifs. Trends Cell Biol 9: 323-328, 1999.

4. Li F, Ambrosini G, Chu EY, Plescia J, Tognin S, Marchisio PC and Altieri DC: Control of apoptosis and mitotic spindle checkpoint by survivin. Nature 396: 580-584, 1998.

5. Altieri DC and Marchisio PC: Survivin apoptosis: An interloper between cell death and cell proliferation in cancer. Lab Invest 79: 1327-1333, 1999.

6. Li F, Ackermann EJ, Bennett CF, Rothermel AL, Plescia J, Tognin S, Villa A, Marchisio PC and Altieri DC: Pleiotropic cell-division defects and apoptosis induced by interference with survivin function. Nat Cell Biol 1: 461-466, 1999.

7. Chantalat L, Skoufias DA, Kleman JP, Jung B, Dideberg O and Margolis RL: Crystal structure of human survivin reveals a bow tie-shaped dimer with two unusual alpha-helical extensions. Mol Cell 6: 183-189, 2000

8. Mahotka C, Wenzel M, Springer E, Gabbert HE and Gerharz CD: Survivin-deltaEx 3 and survivin-2B: Two novel splice variants of the apoptosis inhibitor survivin with different antiapoptotic properties. Cancer Res 59: 6097-6102, 1999.

9. Badran A, Yoshida A, Ishikawa K, Goi T, Yamaguchi A, Ueda T and Inuzuka M: Identification of a novel splice variant of the human anti-apoptopsis gene survivin. Biochem Biophys Res Commun 314: 902-907, 2004.

10. Caldas H, Honsey LE and Altura RA: Survivin 2alpha: A novel Survivin splice variant expressed in human malignancies. Mol Cancer 4: 11, 2005.

11. Reed JC: The Survivin saga goes in vivo. J Clin Invest 108: 965-969, 2001.

12. Satoh K, Kaneko K, Hirota M, Masamune A, Satoh A and Shimosegawa T: Expression of survivin is correlated with cancer cell apoptosis and is involved in the development of human pancreatic duct cell tumors. Cancer 92: 271-278, 2001.

13. Tanaka C, Uzawa K, Shibahara T, Yokoe H, Noma H and Tanzawa H: Expression of an inhibitor of apoptosis, survivin, in oral carcinogenesis. J Dent Res 82: 607-611, 2003.

14. Dallaglio K, Marconi A and Pincelli C: Survivin: A dual player in healthy and diseased skin. J Invest Dermatol 132: 18-27, 2012.

15. Dohi T, Beltrami E, Wall NR, Plescia J and Altieri DC: Mitochondrial survivin inhibits apoptosis and promotes tumorigenesis. J Clin Invest 114: 1117-1127, 2004.

16. Fortugno P, Wall NR, Giodini A, O'Connor DS, Plescia J, Padgett KM, Tognin S, Marchisio PC and Altieri DC: Survivin exists in immunochemically distinct subcellular pools and is involved in spindle microtubule function. J Cell Sci 115: 575-585, 2002.

17. Dohi T, Okada K, Xia F, Wilford CE, Samuel T, Welsh K, Marusawa H, Zou H, Armstrong R, Matsuzawa S, et al: An IAP-IAP complex inhibits apoptosis. J Biol Chem 279: 34087-34090, 2004.

18. Khan S, Jutzy JM, Aspe JR, McGregor DW, Neidigh JW and Wall NR: Survivin is released from cancer cells via exosomes. Apoptosis 16: 1-12, 2011. 
19. Wright ME, Han DK and Hockenbery DM: Caspase-3 and inhibitor of apoptosis protein(s) interactions in Saccharomyces cerevisiae and mammalian cells. FEBS Lett 481: 13-18, 2000.

20. Song $Z$, Yao $X$ and Wu M: Direct interaction between survivin and Smac/DIABLO is essential for the anti-apoptotic activity of survivin during taxol-induced apoptosis. J Biol Chem 278 : 23130-23140, 2003

21. Tamm I, Wang Y, Sausville E, Scudiero DA, Vigna N, Oltersdorf T and Reed JC: IAP-family protein survivin inhibits caspase activity and apoptosis induced by Fas (CD95), Bax caspases, and anticancer drugs. Cancer Res 58: 5315-5320, 1998

22. Chen J, Wu W, Tahir SK, Kroeger PE, Rosenberg SH, Cowsert LM, Bennett F, Krajewski S, Krajewska M, Welsh K, et al: Down-regulation of survivin by antisense oligonucleotides increases apoptosis, inhibits cytokinesis and anchorage-independent growth. Neoplasia 2: 235-241, 2000.

23. Olie RA, Simões-Wüst AP, Baumann B, Leech SH, Fabbro D, Stahel RA and Zangemeister-Wittke U: A novel antisense oligonucleotide targeting survivin expression induces apoptosis and sensitizes lung cancer cells to chemotherapy. Cancer Res 60 : 2805-2809, 2000.

24. Chandele A, Prasad V, Jagtap JC, Shukla R and Shastry PR: Upregulation of survivin in $\mathrm{G} 2 / \mathrm{M}$ cells and inhibition of caspase 9 activity enhances resistance in staurosporine-induced apoptosis. Neoplasia 6: 29-40, 2004

25. Suzuki A, Hayashida M, Ito T, Kawano H, Nakano T, Miura M, Akahane K and Shiraki K: Survivin initiates cell cycle entry by the competitive interaction with Cdk4/p16(INK4a) and Cdk2/cyclin E complex activation. Oncogene 19: 3225-3234, 2000.

26. Jeyaprakash AA, Klein UR, Lindner D, Ebert J, Nigg EA and Conti E: Structure of a Survivin-Borealin-INCENP core complex reveals how chromosomal passengers travel together. Cell 131: 271-285, 2007.

27. D'Avino PP and Capalbo L: New Auroras on the roles of the chromosomal passenger complex in cytokinesis: Implications for cancer therapies. Front Oncol 5: 221, 2015.

28. Li Y, Liu D, Zhou Y, Li Y, Xie J, Lee RJ, Cai Y and Teng L: Silencing of survivin expression leads to reduced proliferation and cell cycle arrest in cancer cells. J Cancer 6: 1187-1194, 2015

29. Hagenbuchner J, Kiechl-Kohlendorfer U, Obexer P and Ausserlechner MJ: BIRC5/Survivin as a target for glycolysis inhibition in high-stage neuroblastoma. Oncogene 35: 2052-2061, 2016

30. Véquaud E, Séveno C, Loussouarn D, Engelhart L, Campone M, Juin P and Barillé-Nion S: YM155 potently triggers cell death in breast cancer cells through an autophagy-NF-kB network. Oncotarget 6: 13476-13486, 2015.

31. Ding YH, Fan XD, Wu JJ, Deng ZK, Wei B and Li YF: Effect of YM155 on Apoptosis and Autophagy of K562 Cells. Zhongguo Shi Yan Xue Ye Xue Za Zhi 23: 375-380, 2015 (In Chinese).

32. Jiang G, Ren B, Xu L, Song S, Zhu C and Ye F: Survivin may enhance DNA double-strand break repair capability by up-regulating Ku70 in human KB cells. Anticancer Res 29: 223-228, 2009.

33. Véquaud E, Desplanques G, Jézéquel P, Juin P and Barillé-Nion S: Survivin contributes to DNA repair by homologous recombination in breast cancer cells. Breast Cancer Res Treat 155: 53-63, 2016.

34. Torre LA, Bray F, Siegel RL, Ferlay J, Lortet-Tieulent J and Jemal A: Global cancer statistics, 2012. CA Cancer J Clin 65: 87-108, 2015

35. Jia X, Gao Y, Zhai D, Liu J, Wang Y, Jing LI and Du Z: Survivin is not a promising serological maker for the diagnosis of hepatocellular carcinoma. Oncol Lett 9: 2347-2352, 2015.

36. You WANG, Qing-yun ZHANG, Ya-ming WANG and Jian-jun XU: Cloning of survivin gene and preparation its monoclonoal antibodies as well as checking survivin expression in liver carcinoma cells. Clin J Lab Med 29: 258-262, 2006.

37. Li X, Wang Y, Xu J and Zhang Q: Sandwich ELISA for detecting urinary Survivin in bladder cancer. Chin J Cancer Res 25: 375-381, 2013

38. Liu C, Guo J, Qu L, Bing D, Meng L, Wu J and Shou C: Applications of novel monoclonal antibodies specific for synuclein-gamma in evaluating its levels in sera and cancer tissues from colorectal cancer patients. Cancer Lett 269: 148-158, 2008

39. Jamshidian $H$, Kor $K$ and Djalali $M$ : Urine concentration of nuclear matrix protein 22 for diagnosis of transitional cell carcinoma of bladder. Urol J 5: 243-247, 2008.

40. Önal B, Han Ü, Yilmaz S, Köybasioglu F and Altuğ U: The use of urinary nuclear matrix protein 22 (NMP22) as a diagnostic adjunct to urine cytology for monitoring of recurrent bladder cancer--institutional experience and review. Diagn Cytopathol 43: $307-314,2015$
41. Sah NK and Seniya C: Survivin splice variants and their diagnostic significance. Tumour Biol 36: 6623-6631, 2015.

42. Srivastava AK, Singh PK, Srivastava K, Singh D, Dalela D, Rath SK, Goel MM and Brahma Bhatt ML: Diagnostic role of survivin in urinary bladder cancer. Asian Pac J Cancer Prev 14: 81-85, 2013.

43. Eissa S, Swellam M, Shehata H, El-Khouly IM, El-Zayat T, El-Ahmady O: Expression of HYAL1 and survivin RNA as diagnostic molecular markers for bladder cancer. J Urol 183: 493-498, 2010.

44. PlewkaD,Jakubiec-Bartnik B,Morek M,BoguniaE,Bienioszek M, Wolski H, Kotrych D, Dziekan K, Seremak-Mrozikiewicz A and Plewka A: Survivin in ovary tumors. Ginekol Pol 86: 525-530, 2015.

45. Zhang Y, Wang J, Sui X, Li Y, Lu K, Fang X, Jiang Y and Wang $X$ : Prognostic and clinicopathological value of survivin in diffuse large B-cell lymphoma: A meta-analysis. Medicine (Baltimore) 94: e1432, 2015.

46. Akhtar M, Gallagher L and Rohan S: Survivin: Role in diagnosis, prognosis, and treatment of bladder cancer. Adv Anat Pathol 13: 122-126, 2006.

47. Goričar K, Kovač V, Franko A, Dodič-Fikfak M and Dolžan V: Serum survivin levels and outcome of chemotherapy in patients with malignant mesothelioma. Dis Markers 2015: 316739, 2015.

48. Yu CJ, Ou JH, Wang ML, Jialielihan N and Liu YH: Elevated survivin mediated multidrug resistance and reduced apoptosis in breast cancer stem cells. J BUON 20: 1287-1294, 2015.

49. Lee MR, Ji SY, Mia-Jan K and Cho MY: Chemoresistance of CD133(+) colon cancer may be related with increased survivin expression. Biochem Biophys Res Commun 463: 229-234, 2015.

50. Cheng Q, Ling X, Haller A, Nakahara T, Yamanaka K, Kita A, Koutoku H, Takeuchi M, Brattain MG and Li F: Suppression of survivin promoter activity by YM155 involves disruption of Sp1-DNA interaction in the survivin core promoter. Int J Biochem Mol Biol 3: 179-197, 2012.

51. Kudchadkar R, Ernst S, Chmielowski B, Redman BG, Steinberg J, Keating A, Jie F, Chen C, Gonzalez R and Weber J: A phase 2, multicenter, open-label study of sepantronium bromide (YM155) plus docetaxel in patients with stage III (unresectable) or stage IV melanoma. Cancer Med 4: 643-650, 2015

52. Carrasco RA, Stamm NB, Marcusson E, Sandusky G, Iversen P and Patel BK: Antisense inhibition of survivin expression as a cancer therapeutic. Mol Cancer Ther 10: 221-232, 2011.

53. Hansen JB, Fisker N, Westergaard M, Kjaerulff LS, Hansen HF, Thrue CA, Rosenbohm C, Wissenbach M, Orum H and Koch T: SPC3042: A proapoptotic survivin inhibitor. Mol Cancer Ther 7: 2736-2745, 2008

54. Coumar MS, Tsai FY, Kanwar JR, Sarvagalla S and Cheung CH: Treat cancers by targeting survivin: Just a dream or future reality? Cancer Treat Rev 39: 802-811, 2013.

55. Li F: Survivin study: What is the next wave? J Cell Physiol 197: 8-29, 2003.

56. Zeng W, Li H, Chen Y, Lv H, Liu L, Ran J, Sun X, Bieerkehazhi S, Liu Y, Li X, et al: Survivin activates NF- $\kappa B$ p65 via the IKK $\beta$ promoter in esophageal squamous cell carcinoma. Mol Med Rep 13: 1869-1880, 2016.

57. Kim JS, Kim HA, Seong MK, Seol H, Oh JS, Kim EK, Chang JW, Hwang SG and Noh WC: STAT3-survivin signaling mediates a poor response to radiotherapy in HER2-positive breast cancers. Oncotarget 7: 7055-7065, 2016.

58. Johnson DC, Greene PS and Nielsen ME: Surgical advances in bladder cancer: At what cost? Urol Clin North Am 42: 235-252, ix, 2015. ix

59. Macleod LC, Hotaling JM, Wright JL, Davenport MT, Gore JL, Harper $\mathbf{J}$ and White E: Risk factors for renal cell carcinoma in the VITAL study. J Urol 190: 1657-1661, 2013.

60. Setiawan VW, Stram DO, Nomura AM, Kolonel LN and Henderson BE: Risk factors for renal cell cancer: The multiethnic cohort. Am J Epidemiol 166: 932-940, 2007.

61. Antonacopoulou AG, Floratou K, Bravou V, Kottorou A, Dimitrakopoulos FI, Marousi S, Stavropoulos M, Koutras AK, Scopa CD and Kalofonos HP: The survivin -31 snp in human colorectal cancer correlates with survivin splice variant expression and improved overall survival. Anal Cell Pathol (Amst) 33: 177-189, 2010

62. Ge QX, Li YY, Nie YQ, Zuo WG and Du YL: Expression of survivin and its four splice variants in colorectal cancer and its clinical significances. Med Oncol 30: 535, 2013.

63. Muchmore SW, Chen J, Jakob C, Zakula D, Matayoshi ED, Wu W, Zhang H, Li F, Ng SC and Altieri DC: Crystal structure and mutagenic analysis of the inhibitor-of-apoptosis protein survivin. Mol Cell 6: 173-182, 2000. 
64. Caldas H, Jiang Y, Holloway MP, Fangusaro J, Mahotka C, Conway EM and Altura RA: Survivin splice variants regulate the balance between proliferation and cell death. Oncogene 24: 1994-2007, 2005.

65. Necochea-Campion R, Chen CS, Mirshahidi S, Howard FD and Wall NR: Clinico-pathologic relevance of Survivin splice variant expression in cancer. Cancer Lett 339: 167-174, 2013.

66. Li F, Yang J, Ramnath N, Javle MM and Tan D: Nuclear or cytoplasmic expression of survivin: What is the significance? Int J Cancer 114: 509-512, 2005.

67. Piras F, Murtas D, Minerba L, Ugalde J, Floris C, Maxia C, Colombari R, Perra MT and Sirigu P: Nuclear survivin is associated with disease recurrence and poor survival in patients with cutaneous malignant melanoma. Histopathology 50: 835-842, 2007.
68. Hou Y, Hu Q, Liu AG, Zhang LQ and Liu SY: Expression of survivin and its location in bone marrow cells of childhood acute leukemia: Relationship to therapeutic efficacy. Zhongguo Dang Dai Er Ke Za Zhi 8: 101-104, 2006 (In Chinese).

69. Takasu C, Shimada M, Kurita N, Iwata T, Sato H, Nishioka M, Morimoto S, Yoshikawa K, Miyatani T, Kashihara H, et al: Survivin expression can predict the effect of chemoradiotherapy for advanced lower rectal cancer. Int J Clin Oncol 18: 869-876, 2013. 